\title{
Az internetes tartalomszabályozással kapcsolatos új gondolkodási irányok az Amerikai Egyesült Államokban Gosztonyi Gergely
}

Az egyértelmünek látszik, hogy az amerikai megoldás a tartalomszabályozás kapcsán, amely (szinte) teljes immunitást biztosít, felülvizsgálatra szorul, de hogy milyen irányban fog elindulni a szabályozó, az még sokesélyes. A szaporodó problémákat látva felmerült a kérdés egyrészt megvan-e a kellő politikai akarat és bátorság a döntéshozókban az internet, a közösségi média és az óriás techcégek szabályozására, másrészt, hogy ezen techmammutok vajon valóban érdekeltek-e a változásokban, vagy csak az időnyerésre játszanak. A tanulmány a platformszolgáltatók és a szabályozók álláspontjait mutatja be, de hogy melyik fog győzedelmeskedni, az egyelőre kétesélyes.

Kulcsszavak: internet, Amerikai Egyesült Államok, tartalomszabályozás, Facebook, CDA230

\section{New ways of thinking about Internet content regulation in the United States}

It seem to be obvious that the American solution to content regulation, which provides (almost) full immunity, needs to be reviewed. Seeing the growing problems, the question arose whether there is enough political will and courage in decision-makers to regulate the internet, social media and giant tech-companies, and also whether these techmammuts are really interested in change or just playing at times. The study presents the positions of platform providers and regulators, but which one will win is doubtful for the time being.

Keywords: internet, United States of America, content control, Facebook, CDA230

https://doi.org/10.32980/MJSz.2021.4.1257

"Most ehhez a gombhoz kéne a kabát. Lehet, hogy én mindig gombokhoz keresek kabátot?

Rendes szabó nem ilyen. Mit értünk rendesen?"n

\section{Bevezetés}

6 kérdés, ami sokakban felmerült a kétezertízes évek végén, hogy vajon a O szaporodó problémákat (fake news, deepfake, mis- és disinformation, internetes zaklatás, online gátlástalanság, flame war, bosszúpornó, magáncégek és

\footnotetext{
* Egyetemi adjunktus, Eötvös Loránd Tudományegyetem, Állam- és Jogtudományi Kar, Magyar Állam- és Jogtörténeti Tanszék.

${ }^{1}$ Esterházy Péter: Hasnyálmirigynapló. Budapest, Magvető, 2016, 100. o.
} 
államok által folytatott cenzúra stb.) látva egyrészt megvan-e a kellő politikai akarat és bátorság a döntéshozókban az internet, a közösségi média és az óriás techcégek szabályozására, másrészt, hogy ezen techmammutok vajon valóban érdekeltek-e a változásokban, vagy csak az időnyerésre játszanak. Ahogy az Amerikai Legfelsőbb Bíróság fogalmazott - ugyanarra a következtetésre jutva, mint az Emberi Jogok Európai Bírósága (EJEB) a Cengiz és mások kontra Törökország ügyben ${ }^{2}$-: „míg korábban nehézségekbe ütközhetett a véleménynyilvánítás legfontosabb (térbeli értelemben vett) helyeinek meghatározása, ma erre már egyértelmű a válasz: ez a kibertér - általában az 'Internet demokratikus fórumai' és különösen a közösségi média." ${ }^{13}$

Az amerikai szabályozás, amit az 1996-os Telekommunikációs törvény V. fejezetének (közkeletü nevén a kommunikációs tisztességről szóló törvény) 230(c)(1) paragrafusába találhatunk ${ }^{4}$, (szinte) teljes immunitást biztosít számára a harmadik fél által feltöltött tartalomért, és ez még akkor is igaz, amennyiben tudott a tartalom jogellenes voltáról ${ }^{5}$. A 230(c)(2) paragrafus tartalmazza továbbá az "jó szamaritánus" védelmet is a polgári jogi felelősséggel szemben a szolgáltatók által obszcénnek vagy sértőnek ítélt, akár alkotmányosan védett beszédek eltávolítása vagy moderációja esetén mindaddig, amíg jóhiszeműen járnak el.

Az elmúlt években ugyanakkor mind a tudomány, mind a politika, mind pedig a platformszolgáltatók számára egyértelművé vált, hogy a vonatkozó szabályok jelentős felülvizsgálatra szorulnak ${ }^{6}$, így az Amerikai Egyesült Államokban is számos szereplő fejtette ki a véleményét és megoldási javaslatait a témában. Ahogy CsákiHatalovics Gyula Balázs fogalmaz: „Mindkét politikai oldal (demokraták és republikánusok) több képviselője fogalmazott meg elvárásokat (vagy konkrét javaslatokat)"17. Ám mivel a vélemények között kevés átfedés van annak kapcsán, hogy pontosan mit és milyen szereplőnek is lenne szükséges szabályoznia, érdemes részletesen megvizsgálni a különféle amerikai megoldási javaslatokat és szabályozási irányokat.

2 „„Az internet mára az elsődleges eszközzé vált, amelyen keresztül a személyek az információk és ötletek fogadásához és átadásához füződő szabadságukat gyakorolják." Cengiz and Others v. Turkey, no. 48226/10 és 14027/11, 2015. december 1-jei ítélet, 49.

3 Packingham v. North Carolina, 137 S. Ct. 1730, 198 L. Ed. 2d 273 (2017).

${ }^{4}$ Mivel a jelen tanulmányban vizsgált kérdés leginkább a 230 (c)1 paragrafusban található szabályozással kapcsolatos, így erre az amerikai szakirodalomban használt rövidítést (CDA230) használom a továbbiakban. - A szerző.

${ }^{5}$ Zeran v. America Online, 129 F.3d 327 (4th Cir. 1997). Részletesen lásd: Bayer Judit: A háló szabadsága. Az internet tartalmának szabályozási problémái a véleménynyilvánítás szabadsága tükrében. Budapest, Új Mandátum Könyvkiadó - Zsigmond Király Főiskola, 2005, 33. o.

${ }^{6}$ Szőke Gergely László: A közösségi oldalak szabályozási problémái, in: A technológiai fejlődés jogi kihívásai: Kézikönyv a jogalkotás és jogalkalmazás számára (szerk: Kis Kelemen Bence - Mohay Ágoston), Pécs, Pécsi Tudományegyetem Állam- és Jogtudományi Kar, 2021, 105-106. 0.

7 Csáki-Hatalovics Gyula Balázs: A közösségi média személyiségvédelemmel összefüggő kihívásai és szabályozása az Amerikai Egyesült Államokban, in: "Gondolatok köztere". A közösségi média személyiségvédelemmel összefüggő kihívásai és szabályozása az egyes államokban (szerk.: Czékmann Zsolt - Csák Csilla - Barzó Tímea), Miskolc, Miskolci Egyetemi Kiadó, 2021, 616. o. 


\section{A platformszolgáltatók álláspontja a szükséges szabályozás tekintetében}

Mark Zuckerberg Facebook elnök-vezérigazgató 2019-ben a szenátusi meghallgatásán „felszólította a szabályozókat, hogy 'aktívabb szerepet' töltsenek be az internetet irányító szabályok kialakításában". 8 Ennek folyományaként a Washington Post-ban „Az internetnek új szabályokra van szüksége. Kezdjük ezen a négy területen." címmel tett közzé olvasói levelet ${ }^{9}$, amelyet azonban - tartalmát tekintve - akár egy kiáltványként is felfoghatunk. A levél kezdetén elismeri, hogy „a technológia életünk jelentős része, és a vállalatok, mint például a Facebook, hatalmas felelősséggel tartoznak.", majd négy területet jelöl meg (káros tartalom, a választások integritása, az adatvédelem, illetve az adatok hordozhatósága), ahol a szabályozóknak sürgős lépéseket kell tenniük, ha a szaporodó problémákat és az újmédia volumenét tekintve nem kívánnak az események után kullogni.

a) A káros tartalom tartalmak kapcsán megjegyzi, hogy "a törvényalkotók gyakran azt mondják nekem, hogy túl nagy a hatalmunk a szólás felett, és őszintén szólva egyetértek. Meggyőződésem, hogy nem szabad ennyi fontos döntést egyedül hoznunk a szólásról. ${ }^{.10}$ Kiemeli, hogy az összes káros tartalom eltávolítása az internetről lehetetlen feladat technikailag is, ám egy egységesebb szabályrendszer segítheti a tisztánlátást. Természetesen e kérdésben az átláthatóság - mind az államok, mind a techcégek részéről alapkövetelmény lenne.

b) A választások integritása kapcsán a politikai reklámok szabályozása és a politikai kampányok szigorúbb jogi keretek közé terelése mellett érvel.

c) Az adatvédelemmel összefüggésben az Amerikai Egyesült Államokban is a GDPR-hoz hasonló szabályozás meghozatalát javasolja ${ }^{11}$.

d) Negyedikként az adatok hordozhatóságára hívja fel a figyelmet, amely a különféle szolgáltatások és applikációk között nehézkesen valósul meg manapság ${ }^{12}$.

Utolsó gondolatként megosztja a nagyközönséggel, hogy „az internetre vonatkozó szabályok lehetővé tették egy generációnak, hogy olyan szolgáltatásokat építsenek, amelyek megváltoztatták a világot, és rengeteg értéket teremtenek az emberek életében. Frissítsük ezeket a szabályokat, hogy egyértelmüen meghatározzuk az

${ }^{8}$ Christopher Bing: Facebook CEO calls for updated internet regulations, Reuters, 2019. március 31., https://www.reuters.com/article/us-facebook-privacy-regulation-idUSKCN1RBORX (letöltés ideje: 2021. december 17.).

${ }_{9}^{9}$ Mark Zuckerberg: The Internet needs new rules. Let's start in these four areas, The Washington Post, 2019. március 30., https://www.washingtonpost.com/opinions/mark-zuckerberg-the-internet-needsnew-rules-lets-start-in-these-four-areas/2019/03/29/9e6f0504-521a-11e9-a3f7-

78b7525a8d5f_story.html (letöltés ideje: 2021. december 21.).

${ }^{10}$ Zuckerberg: i.m.

${ }^{11}$ Erről még lásd: Shannon Togawa Mercer: The Limitations of European Data Protection As A Model for Global Privacy Regulation, AJIL Unbound, (2020) 114, 20-25. o.

12 Kiemelhető, hogy ezzel a kérdéssel az új, 2020 végi európai digitális rendeletcsomag is foglalkozik: Javaslat az Európai Parlament és a tanács rendelete a digitális ágazat vonatkozásában a megtámadható és méltányos piacokról (digitális piacokról szóló jogszabály), 2020/0374(COD), COM/2020/842 final (továbbiakban: DMA, Digital Markets Act) 6. cikk (1) h). 
emberek, a vállalatok és a kormányok felelősségét a továbbiakban."13 A nagy techcégek az utóbbi pár évben láthatóan előre menekülnek, mivel érzik, hogy mind az Amerikai Egyesült Államokban, mind az Európai Unióban változások következnek be. A folyamat egyik fontos állomása volt a Facebook által 2020-ban kiadott 'Fehér Könyv ${ }^{\prime 14}$, amely négy kulcskérdést azonosított - a kritikusok szerint a vállalat szája íze szerint $-:^{15}$

- Hogyan lehet a tartalomszabályozással a legjobban elérni a káros tartalmak mennyiségének csökkentését a szabad véleménynyilvánítás megőrzése mellett?

- Hogyan lehetne javítani a szabályozással az internetes platformok nyilvánosság előtti elszámoltathatóságát?

- Előírja-e a szabályozás, hogy az internetes vállalatok elérjenek bizonyos teljesítménycélokat?

- Meg kell-e határoznia a szabályozásnak, hogy mely káros tartalmat kell tiltani az internetes platformokon?

A cég az alábbiakkal érvel: „Az emberi jogi normákkal összhangban az internetes platformok általában tiszteletben tartják azoknak az országoknak a törvényeit, amelyekben müködnek, ezen felül pedig szabadon meghatározhatják a megengedett kifejezéssel kapcsolatos saját szabályaikat, amelyek gyakran szigorúbbak, mint a törvények. Ennek eredményeként az internetes vállalatok minden nap döntések elött állnak, amelyek befolyásolják, hogy ki képes beszélni, és milyen tartalmat lehet megosztani a platformjukon." ${ }^{16}$ Kiemelik, hogy sokszor a döntéseiket a nagy tartalomszolgáltatók nem tudják kellően kommunikálni az emberek felé, kiemeli, hogy a döntések napi volumenéből adódóan elkerülhetetlen a hibázás, illetve kiemeli, hogy az illegális tartalmak - bár a közvélemény sokszor szinonimaként kezeli vele és a káros tartalmak kategóriája jelentősen eltér egymástól (ami káros, nem biztos, hogy feltétlenül illegális is). Az internet szabályozása kapcsán négy problémára ${ }^{17}$ világít rá:

- A jogi környezet és a beszéd normái eltérnek a világ különböző országaiban, és mivel a legnagyobb techcégek nemzetközi környezetben szolgáltatnak, ez okozhat egyenetlenségeket.

- A technológia és a beszéd is dinamikus jellegzetességekkel bír, azaz a technológiai folyamatosan változik, mint ahogy a beszéd is, hiszen már eszközzel és máshogy beszélünk a barátainkkal, egy állásinterjún vagy egy államközi online egyeztetésen.

- A végrehajtás mindig tökéletlen lesz, hiszen számos nyelven, nyelvjárásban kell alkalmazni, ráadásul az emberi kommunikációs teljes eszköztárát ismerve az iróniától a dühön át a kegyes hazugságig.

\footnotetext{
${ }^{13}$ Zuckerberg: i.m.

${ }^{14}$ A Fehér Könyv olyan nyomtatott vagy elektronikus kiadvány, amely egy szervezet hivatalosnak tekinthető áláspontját fogalmazza meg egy téma kapcsán.

15 Monika Bickert: Online Content Regulation, Facebook, 2020. február, https://about.fb.com/wpcontent/uploads/2020/02/Charting-A-Way-Forward_Online-Content-Regulation-White-Paper-1.pdf (letöltés ideje: 2021. december 21.).

${ }^{16}$ Bickert: i.m. 3. o.

${ }^{17}$ Bickert: i.m. 6-7. o.
} 
- A vállalatok közvetítők csupán, nem pedig tartalomkészítők.

A 'Fehér Könyv' kapcsán a Facebook vezetője nem csak az Amerikai Egyesült Államokban, hanem az Európai Unióban is próbált lobbizni. 2020. elején Věra Jourova, az Európai Bizottság alelnöke, az európai értékekért és átláthatóságért felelős biztos a számára bemutatott javaslatok kapcsán csak annyit jegyzett meg, hogy „, a felelősség tekintetében messze van az elfogadható mértéktől"18. A Facebook részéről a folyamatot egy hatalmas erőforrásokkal megtámogatott médiakampány ${ }^{19}$ is kísérte mind a televízió, mind a nyomtatott sajtó, mind az internet felületein, ám ezt sokan kritizálták leegyszerűsítő hangneme és tárgyi tévedései miatt ${ }^{20}$.

\section{Egy megoldási kísérlet, avagy a Facebook Ellenőrző Bizottsága}

Fentiek mellett - saját szemszögéből nézve - drasztikusabbnak tünő lépésre is elszánta magát a világ vezető közösségimédia-szolgáltatója: 2020. május 6-án bejelentette, hogy elismert szakértőkből álló független Ellenőrző Bizottságot (Oversight Board) állított fel, amely a problematikus tartalmak kérdésében segíti a céget. "Külső szakértők és közösségi vezetők lévén eleget teszünk feladatunknak, hogy megválaszoljunk néhányat a legnehezebb kérdések közül az online véleménynyilvánítás szabadságával kapcsolatban: hogy mit kell eltávolítani, mit lehet fent hagyni, és miért." - írják ${ }^{21}$.

Az Ellenőrző Bizottságot többen - jogilag nem túl megalapozott módon - a vállalat saját Alkotmánybíróságaként jellemezték ${ }^{22}$, hiszen felülírhatja egy magánvállalat tartalomszabályozással kapcsolatos döntéseit. Fontos ugyanakkor, hogy az Ellenőrző Bizottság csak olyan kérdésekben dönt, amelyek „bonyolultak, jelentősek, globálisan relevánsak és felhasználhatók a Facebook jövőbeni szabályainak megalapozott kidolgozásához." ${ }^{23}$ Mindazonáltal az Ellenőrző Bizottság működése nem változtat még azon a tényen, hogy az államok és annak politikusai továbbra is a szolgáltatókra hárítják a tartalmakról való döntés ódiumát - bár talán a testületben megjelenő szakértelem javíthat a döntések színvonalán. ${ }^{24}$

Ugyan a testület működésének megindulásáról szóló hivatalos bejelentés csak 2020 közepén vált esedékessé, a kiválasztási folyamat már jó másfél éve zajlott

${ }^{18}$ Valentina Pop: Zuckerberg Tells EU Regulators Facebook Wants More Content Liability, The Wall Street Journal, 2020. február 17., https://www.wsj.com/articles/zuckerberg-tells-eu-regulators-facebookwants-more-content-liability-11581961804 (letöltés ideje: 2021. december 17.).

${ }^{19} \mathrm{https}$ ///about.fb.com/regulations/ (letöltés ideje: 2021. december 17.).

20 Mueller Milton: Updated Internet Regulations?, IG Institutions, Platform Governance, 2021. március 22., https://www.internetgovernance.org/2021/03/22/updated-internet-regulations (letöltés ideje: 2021. december 22.).

${ }^{21}$ https://oversightboard.com/meet-the-board/ (letöltés ideje: 2021. december 20.).

22 John Morgan: Scholars overseeing Facebook: Supreme Court or fairness washing?, Times Higher Education, 2021. március 10., https://www.timeshighereducation.com/news/scholars-overseeingfacebook-supreme-court-or-fairness-washing (letöltés ideje: 2021. december 20.).

${ }^{23} \mathrm{https}$ ://oversightboard.com/appeals-process/ (letöltés ideje: 2021. december 17.).

${ }^{24}$ Edison Lanza - Matías Jackson: Content Moderation and Self-Regulation Mechanisms. The Facebook Oversight Board and its Implications for Latin America. Washington, D.C., Inter-American Dialogue, 2021. 
akkor már: offline és online konzultációkat is tartottak szerte a világban ${ }^{25}$. Az eredeti tervek szerint az Ellenőrző Bizottság 40 főből áll majd a jövőben, de már 2021-ben -, amikor a létszám 20 fö -, van köztük „egy volt miniszterelnök, egy Nobelbékedíjas, a The Guardian volt szerkesztője és kilenc akadémikus a világ egyetemeiről." ${ }^{26}$ A kilenc akadémikus egyike Sajó András, az Emberi Jogok Európai Bíróságának volt elnökhelyettese ${ }^{27}$.

A tagokat nagyjából ezer jelöltből választották ki, és a névsort vizsgálva eddig senkiben nem merült fel, hogy ne megalapozott módon történt volna a kiválasztás. A tagok közül Nicola Suzor például így nyilatkozott: "meg akartam ragadni a lehetőséget, hogy a kutatásaimat a gyakorlatba is átültethessem, miután egy évtizedig kiabáltam a techcégeknek, hogy jobban teljesítsenek. Ez egy klassz kísérlet, de nincs garancia arra, hogy müködni fog. Ugyanakkor nagyon szerettem volna mindent megtenni annak érdekében, hogy lássam, mennyire tudom rávenni a Facebook-ot, hogy változtassa meg irányítási és működési gyakorlatát, hogy az megfeleljen az emberi jogi szabályoknak." 28

A testület 2020 decemberében kiválasztotta azon első ügyeket, amelyek kapcsán felülvizsgálja a vállalat döntéseinek helyességét, az első döntések pedig 2021 elején már meg is születtek: az első öt ügyből négy esetben a Facebook moderációs döntésével szemben ítélt a testület, egy esetben pedig jóváhagyta a moderátorok korábbi döntését ${ }^{29}$. Bár a 2021. decemberéig megszületett huszonegy döntésbő|l ${ }^{30}$ alapos szakmai állásfoglalást még nem lehet levonni, az látható, hogy tizenöt esetben a testület felülbírálta a Facebook tartalom eltávolítására vonatkozó döntését:

\footnotetext{
${ }^{25}$ Kate Klonick: The Facebook Oversight Board: Creating an Independent Institution to Adjudicate Online Free Expression, Yale Law Journal, 129 (2020) 2418., 2451-2457. o.

${ }^{26}$ Morgan: i.m.

${ }^{27} \mathrm{https}$ ://oversightboard.com/meet-the-board/andras-sajo/ (letöltés ideje: 2021. december 17.).

28 Morgan: i.m.

${ }^{29}$ A legelső döntésekről kiváló szakmai elemzést közöl: Szikora Tamás: A Facebook Oversight Board első döntései - meglepetések helyett „papírforma"?, Ludovika Blog, 2021. február 5., https://www.ludovika.hu/blogok/itkiblog/2021/02/05/a-facebook-oversight-board-elso-donteseimeglepetesek-helyett-papirforma/ (letöltés ideje: 2021. december 17.).

${ }^{30} \mathrm{Az}$ Ellenőrző Bizottság összes döntése elolvasható ezen a linken: https://oversightboard.com/decision/ (letöltés ideje: 2021. december 20.).
} 


\begin{tabular}{|l|c|}
\hline Az Ellenőrző Bizottság döntése & $\begin{array}{c}\text { Esetszám } \\
\text { (darab) }\end{array}$ \\
\hline Felülvizsgáltra kiválasztott, de nem vizsgálható eset ${ }^{31}$ & 1 \\
\hline $\begin{array}{l}\text { Az Ellenőrző Bizottság felülbírálja a Facebook tartalom eltávolítására } \\
\text { vonatkozó döntését, és megköveteli32 a bejegyzés visszaállítását. }\end{array}$ & 11 \\
\hline $\begin{array}{l}\text { Az Ellenőrző Bizottság felülbírálja a Facebook tartalom eltávolítására } \\
\text { vonatkozó eredeti döntését. A Bizottság ugyanakkor megjegyzi, } \\
\text { hogy a Facebook a felülvizsgálatra kiválasztás után már } \\
\text { visszaállította a bejegyzést. }\end{array}$ & 4 \\
\hline Az Ellenőrző Bizottság helybenhagyta a Facebook döntését & $5^{33}$ \\
\hline & $\mathbf{2 1}^{34}$ \\
\hline Összesen & \\
\hline
\end{tabular}

Látható tehát, hogy egy esetet technikai okokból nem tudott a testület vizsgálni, és mindössze öt esetben hagyta jóvá a korábbi döntést, ami 24\%-os 'moderátori eredményességi mutató'. Természetesen ez az adat - mivel a testület választja ki azokat az ügyeket, amelyeket vizsgál - semmiképpen sem általánosítható, ám jól mutatja, hogy az Ellenőrző Bizottság felállításához vezető korábbi kritikáknak volt alapjuk. Külön érdekesség, hogy négy esetben a testület - későbbi elmarasztaló döntését be sem várva, a Facebook visszaállította a kérdéses tartalmakat.

A működés első félévének döntéseiben foglaltak alapján megmutatkozhatnak a körvonalai annak is, hogy az Ellenőrző Bizottság milyen koordinátarendszerben képzeli el saját tevékenységét:

- Fontosnak tartották kiemelni, hogy a mesterséges intelligencia általi moderálás - bármilyen emberi kontroll nélkül - elfogadhatatlan az emberi jogok szempontjából.

31 „A felülvizsgálatra kiválasztott eset egy bejegyzéshez füzött hozzászólásra vonatkozott, amelyben a hozzászólást közzétevő felhasználó a Facebook által hozott, eltávolítást eredményező döntés visszavonását kérte. Ugyanakkor magát a bejegyzést, amely továbbra is elérhető maradt a platformon, később törölte annak közzétevője, így a hozzászólást - az eredeti bejegyzés nélkül - nem lehet már visszaállítani." 2020-001-FB-UA, https://oversightboard.com/decision/FB-KBHZS8BL/ (letöltés ideje: 2021. december 20.).

32 Érdekesség, hogy bár az Ellenőrző Bizottság következetesen a 'require' igét használja döntései során, a döntések magyar változatai ezt többféleképpen ('kéri', 'megköveteli', 'elöírja', 'elvárja') fordítják, amely bár a magyar nyelv sokféleképpét mindenképpen jelzi, félrevezető lehet az igék közötti különbségeket illetően.

${ }^{33}$ A döntés, amely az összes közül a legnagyobb figyelmet kapta, a korábbi amerikai elnök, Donald Trump határozatlan időre történő letiltása volt. Az Ellenőrző Bizottság 2021-001-FB-FBR számon foglalkozott a kérdéssel (https://oversightboard.com/decision/FB-691QAMHJ/ (letöltés ideje: 2021. december 20.)). Mivel a döntés részletes vizsgálata túllépne e könyv keretein, így itt csak Lénárd Sándor izgalmas gondoltakísérletét érdemes említeni a magánvállalatok és a nemzetközi emberi jogi egyezmények kapcsolatáról, miszerint "nem kizárt, hogy a nemzetközi emberi jogok alkalmazása mögött valójában az a megfontolás áll, hogy a Facebook államként vagy legalábbis állami funkciót ellátó vállalatként kíván saját magára tekinteni." Lénárd Sándor: Kié az utolsó szó? A Facebook Ellenőrző Bizottság döntésének margójára, Ludovika Blog, $2021 . \quad$ május https://www.ludovika.hu/blogok/frontierblog/2021/05/25/kie-az-utolso-szo/ (letöltés ideje: 2021. december 20.).

34 2021. december 20-i állapot szerint. - A szerző. 
- Kiemelték, hogy a moderálás során nem csupán a kérdéses tartalmat, hanem annak szöveg- és képi környezetét is vizsgálni szükséges

- Külön hangsúlyt fektettek, hogy a Facebook számára erősen javasolják, hogy a felhasználók által megismerhető szabályok világosak, egyértelmúek, kiszámíthatóak és előreláthatóak legyenek.

- A Facebook közösségi alapelveinek és belső végrehajtási alapelveinek minél több nyelvre és nyelvjárásra való lefordítását javasolják.

- A Bizottság aggályosnak tartotta, hogy a Facebook több éven keresztül nem alkalmazott egy saját belső szabályzatával kapcsolatos kivételszabályt, és hogy ez számos más bejegyzés téves eltávolításához vezethetett.

- Több esetben javasolta a testület, hogy a tartalom eltávolítása helyett jogilag megalapozottabb lenne a szólásszabadságot kevésbé korlátozó eszközöket használni (például figyelmeztető üzenetek vagy akár hangjelzés formájában). A problémák sokak szerint nem az testület összetételében vagy első döntéseiben, hanem máshol keresendők. Julie Cohen szerint a „sztárokkal teli Ellenőrző Bizottság és annak pazar finanszírozása ${ }^{35}$ megakadályozza a későbbi jogi szabályozást, miközben lehetővé teszi a vállalat számára, hogy az ellentmondásos döntéseket kiszervezze." ${ }^{36}$ Ehhez hasonlót fogalmazott meg Laurence Tribe is -, aki az akadémikusok és aktivisták által 2020. novemberében létrehozott 'Igazi Facebook Ellenőrző Bizottság'37 tagja -, miszerint: „olyan legitimációs patinát generál, amelyet a testület összetétele vagy funkciója valójában nem fog alátámasztani". Mindkettőjük álláspontja szerint az Ellenőrző Bizottság csupán a nagyközönség (és természetesen még inkább az amerikai és európai politikusok) megtévesztésére szolgáló testület, amely elvonja a figyelmet a valódi történések elöl és figyelemelterelésként szolgál. Szikora Tamás problémaként veti fel azt is, hogy „egyes konkrét tartalmakat érint” 'végső' döntés kimondásáig az utóbb jogsértőnek ítélt tartalom mindvégig elérhető lehet a nyilvánosság számára. Ez a körülmény pedig, ismerve a közösségi médiában terjedő információk sebességét, komoly károkat eredményezhet." "38

Dipayan Ghosh a Harvard Business Review-ban kritikaként a következőket jegyzi meg: „Felületesen szemlélve az Ellenőrző Bizottság figyelemre méltó válasz egy új problémára. A világszerte jóval több mint kétmilliárd felhasználóval rendelkező cég súlyos problémák széles skáláját tapasztalta a fó profiljaként szolgáló

${ }^{35}$ A vállalat 130 millió dollárt (39 772315757 forintot) szán az Ellenőrző Bizottság múködtetésére, és arra számít, hogy ez a pénz körülbelül hat évre lesz elegendő. Elizabeth Culliford: Facebook pledges $\$ 130$ million to content oversight board, delays naming members, Reuters, 2019. december 12 ., https://www.reuters.com/article/facebook-oversight-idINKBN1YG23E (letöltés ideje: 2021. december 17.).

${ }^{36}$ Kate Klonick: Inside the Making of Facebook's Supreme Court, The New Yorker, 2021. február 12., https://www.newyorker.com/tech/annals-of-technology/inside-the-making-of-facebooks-supremecourt (letöltés ideje: 2021. december 17.).

37 Mike Butcher: The Real Facebook Oversight Board launches to counter Facebook's Oversight Board, TechCrunch, 2020. szeptember 30., https://techcrunch.com/2020/09/30/the-real-facebook-oversightboard-launches-to-counter-facebooks-oversight-board/ (letöltés ideje: 2021. december 17.).

38 Szikora Tamás: Vajon miben hoz érdemi változást a Facebook újonnan felállt felügyeleti szerve?, Ludovika Blog, 2020. május 25., https://www.ludovika.hu/blogok/itkiblog/2020/05/25/vajon-mibenhoz-erdemi-valtozast-a-facebook-ujonnan-felallt-felugyeleti-szerve/ (letöltés ideje: 2021. december 17.). 
tartalomterjesztés kapcsán."139 Álláspontja szerint nem a tartalommoderálás rossz gyakorlati kivitelezése a problémák oka, hanem maga a modell, amiben ezen óriási techcégek müködnek. A modell, amely szerint nem tartalmat terjesztenek, hanem hirdetést adnak el, és amely modellben a tartalom igazából másodlagos ${ }^{40}$. Bonyolult algoritmusokra és a személyes adatok minél teljeskörübb begyűjtésére támaszkodik, hogy ezeket a hirdetéséket minél inkább és minél automatikusabb módon személyre tudja szabni a sokmillió felhasználó számára. A felhasználók így „bármilyen tartalmat megkapnak, amelyről a platform úgy gondolja, hogy maximalizálja a saját profitját." ${ }^{\prime 41}$ A probléma kezelésére így az Ellenőrző Bizottság által elvégzett átvilágítása egyes problémáknak és egyes felhasználói tartalmaknak nem elegendő, hiszen például a fő problémák (egyikét) okozó politikai kampányok ellenőrzéséhez nem férhetnek hozzá. Mindaddig, amíg maguknak a nagy cégeknek a működési mechanizmusa nem változik, addig egyes ügyek vizsgálatával rendszerszintü változásokat nem lehet elérni.

Ghosh az Ellenőrző Bizottság hatáskörének jelentős kiszélesítésében látja a megoldást ${ }^{42}$ : nem csupán a tartalmak eltávolítása kapcsán lehetne lehetősége döntéseket hozni, hanem akár a vállalat adatkezelési gyakorlata, felvásárlási szándékai vagy akár a fogyasztóvédelem terén. Így az Ellenőrző Bizottság - a nevének megfelelően - nem csupán egy szépségfolt lenne, hanem valódi felügyeleti eszköz. A világ legnagyobb cégének a problémák kellős közepén példát kellene mutatnia. De mindez már átvezet a következő kérdéshez, hogy milyen irányba lenne érdemes elmozdulnia az amerikai szabályozásnak.

\section{A lehetséges szabályozási utak}

Elsőnek érdemes azt az amerikai álláspontot tisztázni, hogy létezik-e „átfogó internetszabályozás"43, ahogy a Facebook hirdetéseiben és kampányában szerepel. A fent ismertetett CDA230 ugyan az Internet egyik alapvető kérdéskörét szabályozza, de teljeskörű szabályozásnak nehezen lehetne nevezni. Ezzel összekapcsolható kérdés, ami szintén megjelenik a kampányban, hogy „azóta nem történt semmi az internet szabályozása terén". ${ }^{44}$ Ezzel kapcsolatban Milton megjegyzi, hogy „a 105. kongresszus (1997-1998) és a 116. kongresszus (20192021) között több mint 300, az internethez kapcsolódó törvényjavaslatot fogadott el az amerikai kongresszus." ${ }^{\prime 4}$ Ezek közül az egyik legfontosabb pedig a

\footnotetext{
39 Dipayan Ghosh: Facebook's Oversight Board Is Not Enough, Harvard Business Review, 2019. október 16., https://hbr.org/2019/10/facebooks-oversight-board-is-not-enough (letöltés ideje: 2021. december 17.).

${ }^{40}$ Ahogy Siva Vaidhyanathan frappánsan megfogalmazta: „A Facebook-kal a Facebook a probléma”. Siva Vaidhyanathan: Antisocial Media: How Facebook Disconnects Us and Undermines Democracy, Oxford, Oxford University Press, 2018.

${ }^{41}$ Ghosh: i.m.

42 Ghosh: i.m.

${ }^{43}$ https://about.fb.com/regulations/ (letöltés ideje: 2021. december 20.).

44 U.o.

${ }^{45}$ Milton, i.m.
} 
netsemlegességre vonatkozó szabályok elfogadása 2015-ben a Szövetségi Távközlési Bizottság (Federal Communications Commission, FCC $^{46}$ ) által. ${ }^{47}$ Bár ez utóbbi jogilag megkérdőjeleződött (bírósági eljárásban ${ }^{48}$ ) és átdolgozásra is került (az akkor új, Trump-elnöki adminisztráció által ${ }^{49}$ ), 2021. július 9-én Joe Biden elnök 14036-os számú elnöki rendeletben ${ }^{50}$ utasította az FCC-t a netsemlegességi szabályok visszaállítására.

Tom Wheeler -, aki 2013 és 2017 között az FCC elnöke volt - amellett érvel ${ }^{51}$, hogy egy új szabályozó hatóságot kell létrehozni, hiszen az FCC számos módon túlterhelt (mind az ügyek, mind a hozzá tartozó joghatóság tekintetében), így egy olyan gyorsan változó és számos problémát felvető területen, mint az internet, nem képes ellátni a hatósági feladatokat. Wheeler az új DSA ${ }^{52}$-DMA rendeletjavaslatokat ${ }^{53}$ hozza fel követendő példaként. Álláspontja szerint immár nem csupán technológiai jellegű szabályozásra van szükség, hanem „ezúttal a technikai normák helyett viselkedési normák lennének szükségesek" ${ }^{54} \mathrm{~A}$ felvetett javaslat szerint a techcégek az érintettekkel együttműködésben egy önszabályozó jellegű kódex-javaslatot készítenének, amit azután ennek az új ügynökségnek kellene elfogadnia, így az állami- és az önszabályozás együttes megoldását, azaz a társszabályozást lehetne megfigyelni. ${ }^{55}$ Mindezek mellett az amerikai trösztellenes szabályok módosítását is szükségesnek látja, hiszen „a merev, felülről lefelé irányuló, bürokratikus

\footnotetext{
${ }^{46}$ A Szövetségi Távközlési Bizottság mind az 50 államban, Columbia körzetében és az Egyesült Államok területén szabályozza a rádió, televízió, vezeték, műholdas és kábel útján történő államközi és a nemzetközi kommunikációt. A kongresszus által felügyelt független amerikai kormányzati ügynökség, az FCC az Egyesült Államok első számú hatósága a kommunikációs törvények, a szabályozás és a technológiai innováció terén. https://www.fcc.gov/about-fcc/what-we-do (letöltés ideje: 2021. december 17.).

${ }^{47}$ Protecting and Promoting the Open Internet, 80 FR 19737.

48 United States Telecom Ass'n v. FCC 825 F.3d 674 (D.C. Cir. 2016).

${ }^{49}$ Keith Collins: Net Neutrality Has Officially Been Repealed. Here's How That Could Affect You, The New York Times, 2018. június 11., https://www.nytimes.com/2018/06/11/technology/net-neutralityrepeal.html (letöltés ideje: 2021. december 17.).

50 Executive Order 14036 Promoting Competition in the American Economy, Sec. 2. (k) (i), https://www.federalregister.gov/documents/2021/07/14/2021-15069/promoting-competition-in-theamerican-economy (letöltés ideje: 2021. december 17.).

${ }^{51}$ Tom Wheeler: Facebook Says It Supports Internet Regulation. Here's an Ambitious Proposal That Might Actually Make a Difference, Time, 2021. április 5., https://time.com/5952630/facebook-regulationagency/ (letöltés ideje: 2021. december 17.).

52 Javaslat az Európai Parlament és a tanács rendelete a digitális szolgáltatások egységes piacáról (digitális szolgáltatásokról szóló jogszabály) és a 2000/31/EK irányelv módosításáról, 2020/0361(COD), COM(2020) 825 final (továbbiakban: DSA, Digital Services Act).

${ }^{53} \mathrm{~A}$ javaslatokról részletesen lásd: Gosztonyi Gergely: Az Európai Unió új digitális rendeletcsomagjának irányai, in: Ünnepi tanulmányok a 80 éves Máthé Gábor tiszteletére: Labor est etiam ipse voluptas (szerk.: Peres Zsuzsanna - Bathó Gábor), Budapest, Ludovika Egyetemi Kiadó, 2021, 405-418. o.

54 Wheeler: Facebook Says It Supports Internet Regulation. Here's an Ambitious Proposal That Might Actually Make a Difference.

55 Érdekes példa, hogy minderre a magyar médiatörvény lehetőséget nyújt a 190-202. § alapján. Koltay András - Lapsánszky András: Az új magyar médiaszabályozás alkotmányossági kérdései, Iustum Aequum Salutare, 7 (2011) 2, 136-141. o.
} 
megoldásokat, amelyekhez gyakran előzetes jóváhagyásra volt szükség az innováció terén, szabotálta a digitális korszak gyors üteme." 56

Ugyanitt érdemes megemlíteni, hogy 2020 júniusában az akkori igazságügyi miniszter, William Barr minisztériuma egy jelentést ${ }^{57}$ tett közzé a CDA230 kapcsán. A jelentés kiemeli, hogy "harmadik féltől származó tartalom esetén a szolgáltató kifogás esetén - valószínűleg eltávolítja vagy cenzúrázza a tartalmat, hogy a felelősségi kockázatokat minimalizálja", ezzel pedig óhatatlanul nem jogsértő tartalmak is eltávolításra kerülnek, ami pedig valóban felveti a gazdasági jellegü cenzúra vádját. ${ }^{58}$ Egy azonos időben született igazságügyi miniszteri levélben pedig javaslatot tesz arra, hogy egyértelmüsíteni kellene az immunitás kereteit, hogy a szolgáltatók "a CDA230-at pajzsként maguk előtt tartva ne cenzúrázhassák a törvényes beszédet rosszhiszemúen, a saját felhasználói szabályrendszerükkel is összeegyeztethetetlen módon". ${ }^{59}$ A levél és a jelentés az alábbi kérdések végig gondolását javasolja az Amerikai Egyesült Államok Kongresszusa és Szenátusa számára:

- Általános immunitás biztosítása szükséges-e vagy lehetségesek kivételszabályok bizonyos tartalmak (gyermekvédelem, terrorizmus, internetes zaklatás stb.) esetén?

- Mik a jóhiszeműség feltételei, és ezzel kapcsolatban a rosszhiszeműen eljáró szolgáltatók immunitása megvonható-e?60

- Érdemes-e megkülönböztetni a különböző szolgáltatókat (akár méret, feladat, hozzájárulás alapján) vagy egységes szabályokat kell alkalmazni? Kezelhető-e egységesen jogilag egy egyszemélyes blog és a Facebook, a Twitter vagy a Google?

- A jelenleg látható helyzetben, ahol az internetes ökoszisztémában a nagy halak megeszik a kisebbeket, újabb szabályok alkotása nem jár-e a verseny (további) csökkenésével?

- Meg lehet-e különböztetni a platformszolgáltató saját tartalmait (és így a saját beszédét) harmadik fél által feltöltött tartalomtól (és így beszédtől)?

- Hosszú időre kell-e a szabályokat alkotni vagy átmeneti, a jelen helyzetet rendezőket?

- Meg kell-e tartani a rágalmazást, mint az immunitás alóli kivételszabályt?

- Hogy állapítható meg, hogy egy szolgáltató szerzőnek, szerkesztőnek vagy kiadónak minősül-e?

${ }^{56}$ Tom Wheeler: The Justice Department's Antitrust Lawsuit Against Google Isn't Enough to Stop the Abuses of Big Tech, Time, 2020. október 20., https://time.com/5901696/google-antitrust-case/ (letöltés ideje: 2021. december 22.).

57 U.S. Department of Justice: Section 230 - Nurturing Innovation or Fostering Unaccountability? Key Takeaways and Recommendations, 2020. június, https://www.justice.gov/file/1286331/download (letöltés ideje: 2021. december 22.).

58 Mindezt az EJEB gyakorlata kapcsán vö.: Delfi AS v. Estonia, no. 64569/09, 2015. június 16-i ítélet, 67.: "err on the side of caution to avoid possible subsequent liability.".

59 https://www.justice.gov/file/1319346/download (letöltés ideje: 2021. december 22.).

60 Például egy olyan esetben, amikor a szolgáltató annak ellenére részesült az immunitásból, hogy rosszhiszemü célra jött létre, mivel lőfegyvert árult olyanoknak, akik ettől el voltak tiltva - ráadásul az egyik vásárló utána a vásárolt fegyverrel három embert meg is ölt. (Daniel v. Armslist, LLC, 386 Wis. 2d 449 (Wis. 2019)). 
- Illegális vagy káros tartalomról való tudomás (és nem cselekvés) esetén is fennáll-e az immunitás?

- Hogy kapcsolódik mindez a cenzúra kérdésköréhez?

A kérdések számosabbak a válaszoknál, és az amerikai politikában is láthattuk, ahogy ez a legutolsó kérdés milyen módon került átpolitizálásra. 2020. május 28-án Donald Trump, az akkori elnök kiadja az 13925 -ös számú elnöki rendeletet ${ }^{61}$, amely az online cenzúra visszaszorítását célozza. Maga a szöveg végig az általánosságok szintjén mozog (például: „A Twitter, a Facebook, az Instagram és a YouTube hatalmas, ha nem is példátlan erővel bír a nyilvános események értelmezésének alakításában; cenzúráznak, törölnek vagy eltüntetnek információkat, és ellenőrizni kívánják, hogy az emberek mit láthassanak és mit nem. ${ }^{\prime \prime 2}$ ), ám a CDA230 körüli vitákban szintén az internet szabadsága, a szabad verseny és a véleménynyilvánítása szabadsága mellett tette le az elnöki 'voksot'. 63

A kérdés immár nem csupán az, hogy mi legyen a CDA230 sorsa, hanem hogy milyen utak állnak a platformszolgáltatók felelősségének megállapítása, azaz a kétezerhúszas évek internetjének legfontosabb kérdésének megválaszolása kapcsán. Kyle Langvardt négy utat vázol fel ${ }^{64}$, amelyen a szabályozó el tud indulni:

a) Az állam expressis verbis meghatározza, hogy milyen tartalmak minősülnek illegálisnak, károsnak vagy eltávolítandónak.

b) A felhasználók választhatnak a szolgáltatók által meghatározott különféle felhasználási módon között, így erősítve az egyéni felelősségvállalást.

c) A tartalom moderálásával kapcsolatos irányelvek és eljárások kötelező közzététele.

d) A tartalommoderálás privatizálása, azaz teljes egészében a szolgáltatókra bízva a tartalom közzétételéről való döntést.

Ahogy Kyle Langvardt megjegyzi, egyik út sem jelenti a tökéletes megoldást, hiszen:

a) Az Internet jellegzetességeiből és a szabad kommunikációból adódóan az első megoldás folyamatos állami kontrollt (akár cenzúrát is) igényel. Ez ráadásul a korábban megszokott jogalkotási gyakorlattal is ellentétben állhat - elég csak az alapjogok legmagasabb szintü jogi normában való szabályozásának kötelezettségére gondolnunk. De ha alacsonyabb szintű jogi normában szabályozunk, „a végén valakit megbíznak a cenzúra-algoritmusok biztonsági

${ }^{61}$ Executive Order 13925 Preventing Online Censorship, https://www.federalregister.gov/documents/2020/06/02/2020-12030/preventing-online-censorship (letöltés ideje: 2021. december 10.).

62 U.o. Section 1. Policy.

63 Ugyanakkor Donald Trump, az Amerikai Egyesült Államok elnökeként Twitter-üzenetekben kommunikálva maga is hozzájárult a cenzúra szó valódi tartalmának jelentős elkoptatásához. Ehhez adalék 2019. május 3-i bejegyzése: „Továbbra is figyelemmel kísérem az AMERIKAI POLGÁROK (sic!) cenzúrázását a közösségi média platformjain. Ez az Amerikai Egyesült Államok - és nekünk megvan, amit úgy nevezünk SZÓLÁSSZABADSÁG (sic!)! Monitorozunk és figyelünk, közelről!!", melynek valódi (elnöki) tartalmát nem egyszerü megérteni. Tony Romm: Trump warns he'll 'monitor the censorship' on social media after Facebook banned some far-right leaders, The Washington Post, 2019. május 3., https://www.washingtonpost.com/technology/2019/05/03/trump-jr-accuses-facebook-silencingconservatives-day-after-it-bans-some-far-right-users/ (letöltés ideje: 2021. december 10.).

${ }^{64}$ Kyle Langvardt: Regulating Online Content Moderation, Georgetown Law Journal, 106 (2017) 5, 13531388. 0. 
ellenőrzésével, és ehhez egyfajta szoros, folyamatos szabályozási beavatkozásra lesz szükség a közszférában, amelyhez nincs egyértelmü történelmi párhuzam." ${ }^{\prime 65}$

b) A második megoldás, azaz amikor a felhasználók választhatnak például, hogy felnőtt vagy gyerek nézi az adott oldalt könnyen elvezethet ugyanahhoz a problémához, amikor a felhasználókat - a felelősségvállalás alóli mentesülésre hivatkozva - olyan helyzetekbe hozzák a szolgáltatók, hogy bizonyos tartalmakat csak hazug módon érhetnek el. ${ }^{66}$ Ráadásul a felkínált tartalmak kapcsán könnyen szembesülhetnek a szolgáltatók, hogy a különféle jogi és társadalmi kultúrájú országokban eltér egymástól a különféle tartalmak megítélése, így ami akár legális az egyik országban, könnyen lehet illegális máshol.

c) A harmadik út kapcsán természetszerüleg merülhetnek fel alkotmányossági problémák, egyrészt azzal kapcsolatban, hogy a moderálást irányító algoritmusok részét képezik-e az adott cégek szólásszabadságának ${ }^{67}$, másrészt versenyjogi kérdések is felmerülhetnek egy magánvállalkozás tulajdonjogával kapcsolatban.

d) Bár mondhatjuk, hogy a felhasználók jelentős többségét soha nem cenzúrázta egyik szolgáltató sem, jogilag ez még nem minősül jelentős érvnek a negyedik út kapcsán. A jelentősebb probléma, hogy „egy ilyen rendszerben a szólásszabadság alakját a közvélemény, a piaci nyomás, a kormányzati nyomás és a cégvezetői lelkiismeret határozza meg. ${ }^{\prime 68}$ Ráadásul ebben az esetben a szolgáltatók a feltöltött tartalom folyamatos monitorozására lennének kényszerítve.

\section{Záró gondolatok}

Bár a fentebb vázolt különféle álláspontok számos tekintetben eltérnek egymástól, az egyértelmünek látszik, hogy az amerikai megoldás a tartalomszabályozás kapcsán, amely (szinte) teljes immunitást biztosít, felülvizsgálatra szorul. Azonban az, hogy milyen irányban fog lépéseket tenni a szabályozó, jelenleg még többesélyes: „a szabályozást szigorító kezdeményezésekkel szembeni legfőbb kritika (ugyanis) ${ }^{69}$ az, hogy bárminemü szigorítás egyúttal magával hozza az Első Alkotmánykiegészítés szerinti véleménynyilvánítás szabadságának korlátozását." ${ }^{170}$

\footnotetext{
${ }^{65}$ Langvardt: i.m. 1378. o.

${ }^{66}$ Nem tökéletes analógia erre, de az irány hasonló: a közösségi médiát főszabályként 13 év alatti személyek nem használhatják, és ennek ellenőrzésére a szolgáltatók csupán egy önbevalláson alapuló megoldást használnak a regisztráció során.

${ }^{67}$ Matthew Panzarino: Apple Files Motion To Vacate The Court Order To Force It To Unlock iPhone, Citing Constitutional Free Speech Rights, TechCrunch, 2016. február 25., https://guce.techcrunch.com/copyConsent?sessionId=3_cc-session_fcd249e6-9b52-468c-810b9640bb3f02b7\&lang=en-US (letöltés ideje: 2021. december 22.).

${ }^{68}$ Langvardt: i.m. 1387. 0.

69 Értelmező beszúrás a szerző által.

${ }^{70}$ Csáki-Hatalovics: i.m. 615. o.
} 
Ron Wyden szenátor 2021-ben a kérdéskör komplexitását az alábbiakban foglalta össze: „Mark Zuckerberg tudja, hogy a CDA230 megújítása megerősíti a Facebook pozícióját, mint domináns közösségi média-szolgáltató, és jelentősen megnehezíti az új startupok számára azt, hogy kihívják a 'fejőstehenet' "71. Hiába tűnt úgy, hogy a kilencvenes- és a kétezertizes években elválhat egymástól az amerikai és az európai szabályozási út, az azóta eltelt idő bebizonyította, hogy szoros együttműködés nélkül az államok vereségre vannak ítélve a techmammutokkal szemben. Az Amerikai Egyesült Államokban a Szilícium-völgy és Washington harcában pedig még lehetetlen eldönteni, ki áll nyerésre.

\section{Irodalomjegyzék}

- Bayer Judit: A háló szabadsága. Az internet tartalmának szabályozási problémái a véleménynyilvánitás szabadsága tükrében. Budapest, Új Mandátum Könyvkiadó-Zsigmond Király Főiskola, 2005

- Christopher Bing: Facebook CEO calls for updated internet regulations, Reuters, 2019. március 31.

- Cristiano Lima: Lawmakers rebuff Facebook's proposed internet rules, Politico, 2021. március 24.

- Csáki-Hatalovics Gyula Balázs: A közösségi média személyiségvédelemmel összefüggő kihívásai és szabályozása az Amerikai Egyesült Államokban, in: "Gondolatok köztere". A közösségi média személyiségvédelemmel összefüggő kihivásai és szabályozása az egyes államokban (szerk.: Czékmann Zsolt - Csák Csilla - Barzó Tímea), Miskolc, Miskolci Egyetemi Kiadó, 2021

- Dipayan Ghosh: Facebook's Oversight Board Is Not Enough, Harvard Business Review, 2019. október 16.

- Edison Lanza - Matías Jackson: Content Moderation and Self-Regulation Mechanisms. The Facebook Oversight Board and its Implications for Latin America. Washington, D.C., InterAmerican Dialogue, 2021

- Elizabeth Culliford: Facebook pledges $\$ 130$ million to content oversight board, delays naming members, Reuters, 2019. december 12.

- Esterházy Péter: Hasnyálmirigynapló. Budapest, Magvető, 2016

- Gosztonyi Gergely: Az Európai Unió új digitális rendeletcsomagjának irányai, in: Ünnepi tanulmányok a 80 éves Máthé Gábor tiszteletére: Labor est etiam ipse voluptas (szerk.: Peres Zsuzsanna - Bathó Gábor), Budapest, Ludovika Egyetemi Kiadó, 2021

- John Morgan: Scholars overseeing Facebook: Supreme Court or fairness washing?, Times Higher Education, 2021. március 10.

- Kate Klonick: Inside the Making of Facebook's Supreme Court, The New Yorker, 2021. február 12.

- Kate Klonick: The Facebook Oversight Board: Creating an Independent Institution to Adjudicate Online Free Expression, Yale Law Journal, 129 (2020) 2418

- Keith Collins: Net Neutrality Has Officially Been Repealed. Here's How That Could Affect You, The New York Times, 2018. június 11.

- Koltay András - Lapsánszky András: Az új magyar médiaszabályozás alkotmányossági kérdései, Iustum Aequum Salutare, 7 (2011) 2

${ }^{71}$ Cristiano Lima: Lawmakers rebuff Facebook's proposed internet rules, Politico, 2021. március 24., https://www.politico.com/news/2021/03/24/facebook-proposed-internet-rules-477868 (letöltés ideje: 2021. december 20.). 
- Kyle Langvardt: Regulating Online Content Moderation, Georgetown Law Journal, 106 (2017) 5 https://doi.org/10.2139/ssrn.3024739

- Lénárd Sándor: Kié az utolsó szó? A Facebook Ellenőrző Bizottság döntésének margójára, Ludovika Blog, 2021. május 25.

- Mark Zuckerberg: The Internet needs new rules. Let's start in these four areas, The Washington Post, 2019. március 30.

- Matthew Panzarino: Apple Files Motion To Vacate The Court Order To Force It To Unlock iPhone, Citing Constitutional Free Speech Rights, TechCrunch, 2016. február 25.

- Mike Butcher: The Real Facebook Oversight Board launches to counter Facebook's Oversight Board, TechCrunch, 2020. szeptember 30.

- Monika Bickert: Online Content Regulation, Facebook, 2020. február

- Mueller Milton: Updated Internet Regulations?, IG Institutions, Platform Governance, 2021. március 22.

- Shannon Togawa Mercer: The Limitations of European Data Protection As A Model for Global Privacy Regulation, AJIL Unbound, (2020) 114 https://doi.org/10.1017/aju.2019.83

- Siva Vaidhyanathan: Antisocial Media: How Facebook Disconnects Us and Undermines Democracy, Oxford, Oxford University Press, 2018

- Szikora Tamás: A Facebook Oversight Board első döntései - meglepetések helyett „papírforma"?, Ludovika Blog, 2021. február 5.

- Szikora Tamás: Vajon miben hoz érdemi változást a Facebook újonnan felállt felügyeleti szerve?, Ludovika Blog, 2020. május 25.

- Szőke Gergely László: A közösségi oldalak szabályozási problémái, in: A technológiai fejlődés jogi kihívásai: Kézikönyv a jogalkotás és jogalkalmazás számára (szerk: Kis Kelemen Bence - Mohay Ágoston), Pécs, Pécsi Tudományegyetem Állam- és Jogtudományi Kar, 2021

- Tom Wheeler: Facebook Says It Supports Internet Regulation. Here's an Ambitious Proposal That Might Actually Make a Difference, Time, 2021. április 5.

- Tom Wheeler: The Justice Department's Antitrust Lawsuit Against Google Isn't Enough to Stop the Abuses of Big Tech, Time, 2020. október 20.

- Tony Romm: Trump warns he'll 'monitor the censorship' on social media after Facebook banned some far-right leaders, The Washington Post, 2019. május 3.

- U.S. Department of Justice: Section 230 - Nurturing Innovation or Fostering Unaccountability? Key Takeaways and Recommendations, 2020. június

- Valentina Pop: Zuckerberg Tells EU Regulators Facebook Wants More Content Liability, The Wall Street Journal, 2020. február 17 